LETTERS

\title{
Multiple rib infarcts: a rare form of osteonecrosis in antiphospholipid syndrome
}

W-H Yoo

O steonecrosis $(\mathrm{ON})$ is a well known morbidity of several rheumatic diseases, usually affecting the hip, knee, shoulder, and ankle. The involvement of multiple or atypical sites by ON has been reported, especially in association with antiphospholipid antibodies (aPL). Rib infarction has been reported as a painful crisis of sickle cell disease, but has not been reported in rheumatic diseases. I describe here the first case of rib infarcts which developed in a patient with mixed connective tissue disease (MCTD) and secondary antiphospholipid syndrome (APS).

\section{CASE REPORT}

A 36 year old woman with hand oedema, Raynaud's phenomenon, and polyarthritis of both hands was diagnosed as having MCTD 3 years ago. She had deep venous thromboses in both legs 2 years ago. Laboratory tests showed an antinuclear antibody titre of $1 / 2560$, IgG anticardiolipin antibody 65.42 GPU (normal <15 GPU), and anti-UIRNP antibody (1/1280). Secondary APS associated with MCTD was diagnosed, and treatment with low dose steroid, aspirin, and warfarin was prescribed.

Recently, she presented with a 15 day history of diffuse, bilateral chest pain. Physical examination disclosed tenderness on multiple ribs. Laboratory findings showed an increased leucocyte count of $11.5 \times 10^{9} / 1$, decreased platelet count of $85 \times 10^{9} / 1$, and an increased erythrocyte sedimentation rate of $36 \mathrm{~mm} / \mathrm{lst} \mathrm{h}$. Coagulation tests showed an activated partial thromboplastin time of 72.4 seconds, and other tests were within the normal range. Immunological studies showed C reactive protein of $125 \mathrm{mg} / \mathrm{l}$ (normal <50) and IgG anticardiolipin antibody 45.63 GPU. Other immunological tests including anti-Sm, anti-dsDNA antibody, cryoglobulins, homocysteine were normal or negative.

Bone scintigraphy showed non-uniform uptake, with areas of decreased and increased uptake in the anterior and lateral aspects of multiple ribs, bilaterally (fig 1). Histological analysis confirmed multiple ON of the ribs (fig 2). She was prescribed with simple analgesics in addition to previous drugs. Her chest pain improved dramatically over the following week and her disease was stable on follow up.

\section{DISCUSSION}

In this report, I describe a rare case of multiple rib infarcts in a patient with secondary APS who had been managed with low dose glucocorticoid. Two interesting points about this case should be emphasised. The first is the pathogenesis of ON. ON has obvious association with various systemic conditions, including sickle cell disease, prolonged glucocorticoid treatment, alcohol abuse, and Gaucher's disease, and several factors, such as vascular thrombosis, mechanical defects, cellular damage, embolisation, changes in intraosseous pressure, or trauma, have been proposed in its pathogenesis. ${ }^{1}$ For rheumatological diseases, a pathogenic relationship between aPL and ON has been proposed on the basis of clinical observations of patients with APS who developed $\mathrm{ON}$ in the absence of glucocorticoid treatment. ${ }^{2}$ Several studies showed a correlation between aPL and ON in patients with systemic lupus erythematosus, ${ }^{4-6}$ and Belmonte et $\mathrm{al}^{7}$ suggested a possible association of aPL with ON in patients with HIV infection.

Multiple rib infarcts in this case strongly suggest that a systemic process may be the underlying pathogenesis. Corticosteroid use and the vasculitic process can be considered to be the causative factors in this case. However, ON in this patient was controlled with a relatively small dose of corticosteroid, and clinical disease was relatively inactive when ON was diagnosed. Whether aPL are directly responsible for this condition or whether they are present as bystanders remains controversial. But, owing to the hypercoagulable potential of aPL, vascular occlusion or thrombotic vasculopathy related to the aPL was also thought to be the underlying pathogenetic mechanism. Thus, the prothrombotic potential of aPL and the above described clinical features of this patient suggest that aPL are directly implicated in the aetiopathogenesis of ON.

The second point which should be emphasised is the atypical presentation of ON affecting the ribs bilaterally. This is an unusual, first described presentation of ON developing on multiple ribs bilaterally. Rib infarction has been reported rarely as a painful crisis of sickle cell disease and associated with vaso-occlusive phenomena. ${ }^{8}$ Although the involvement of multiple or atypical sites (that is, vertebral body and lunate bone) has been reported in association with aPL or catastrophic APS, rib infarcts have not been reported in rheumatic diseases. I suggest that rib infarcts may be an unusual complication of rheumatic diseases with prothrombotic potentials, especially APS.

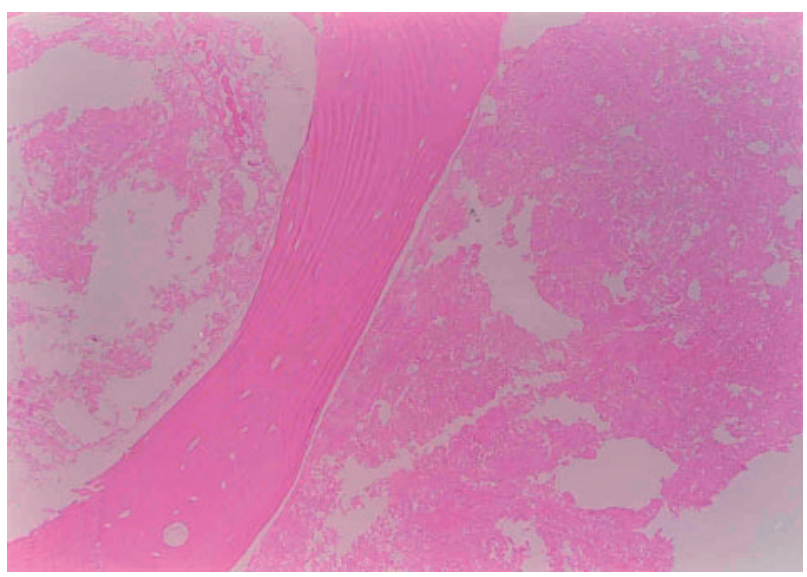

Figure 2 Histological examination of trabecular bone shows the signs of bone death. The trabeculae are preserved, but the lacunae are empty and the marrow is dead (haematoxylin and eosin $\times 100$ ). 

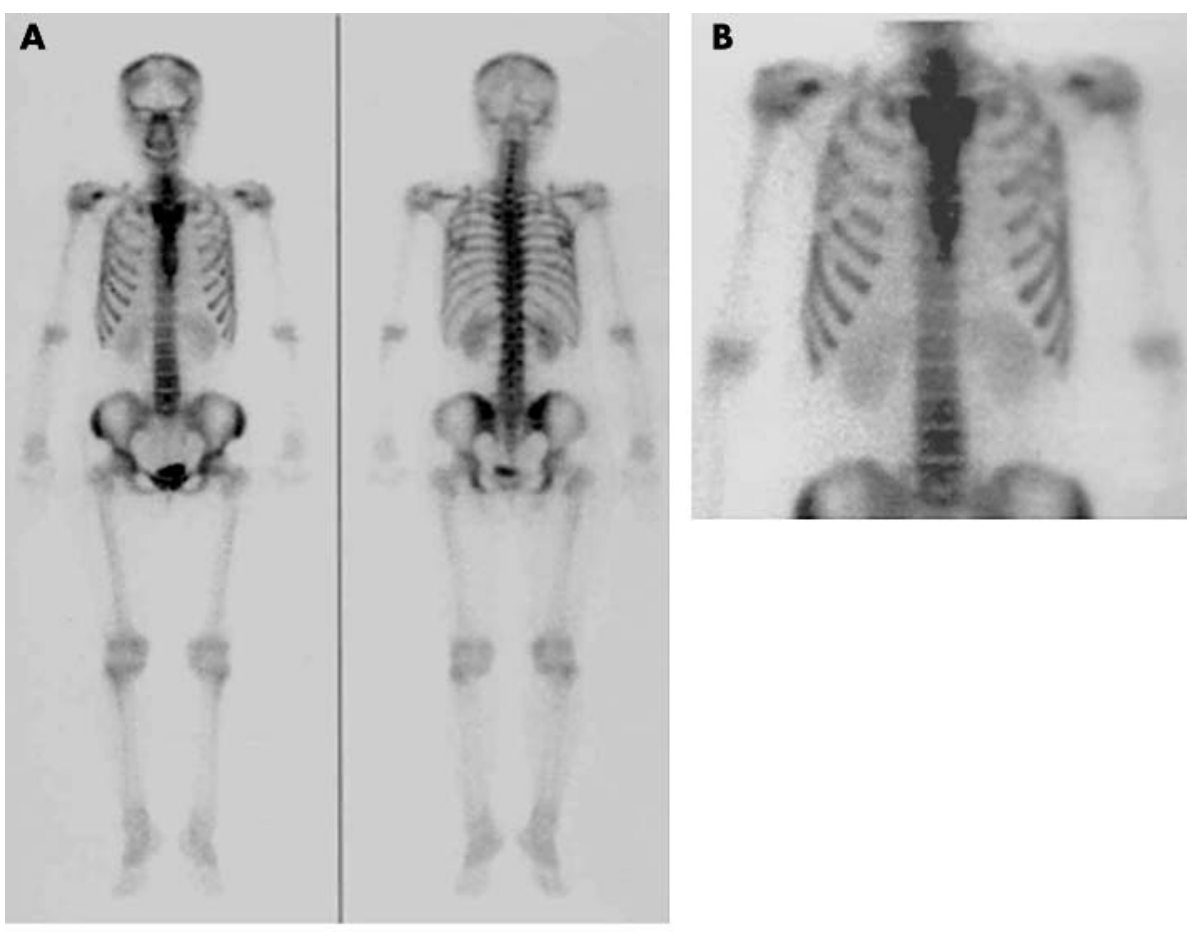

Figure 1 Bone scintigrams of whole body $(A)$, anterior $(B)$, lateral and oblique (C) views of the chest show multiple areas of decreased and increased uptake in the ribs, consistent with bone infarction.

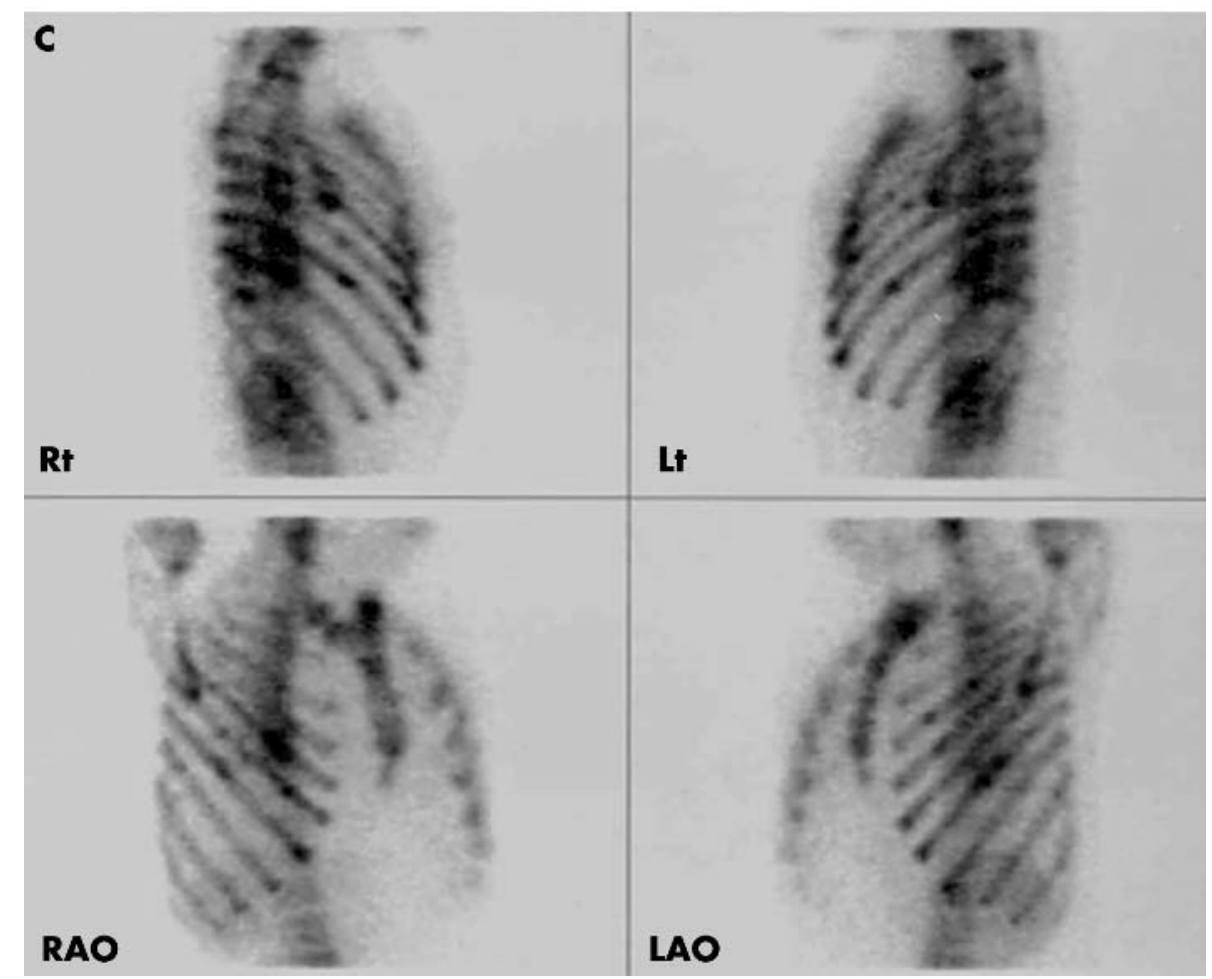

Correspondence to: Dr W-H Yoo, 634-18, Keum-Am Dong, Duck-Jin Gu, Chonju, Chonbuk, 561-712, Korea; ywhim@moak.chonbuk.ac.kr

Accepted 12 June 2003

\section{REFERENCES}

1 Asherson RA. XVlth Internal Congressof Rheumatology. Sydney Australia. 1985:282.

2 Seleznick MJ, Silveira LH, Espinoza LR. Avascular necrosis associated with anticardiolipin antibodies. J Rheumatol 1991;18:1416-17.

3 Alijotas J, Argemi M, Barquinero J. Kienbock's disease and antiphospholipid antibodies. Clin Exp Rheumatol 1990;8:297-8.
4 Asherson RA, Liote F, Page B, Meyer O, Buchanan N, Khamashta MA, et al. Avascular necrosis of bone and antiphospholipid antibodies in systemic lupus erythematosus. J Rheumatol 1993;20:284-8.

5 Nagasawa K, Ishii Y, Mayumi T, Tada Y, Ueda A, Yamauchi $Y$, et al. Avascular necrosis of bone in systemic lupus erythematosus: possible role of haemostatic abnormalities. Ann Rheum Dis 1989;48:672-6.

6 Mont MA, Fairbank AC, Petri M, Hungerford DS. Core decompression for osteonecrosis of the femoral head in systemic lupus erythematosus. Clin Orthop 1997:334:91-7.

7 Belmonte MA, Garcia-Portales R, Domenech I, Fernandez-Nebro A, Camps MT, De Ramon E. Avascular necrosis of bone in human immunodeficiency virus infection and antiphospholipid antibodies.J Rheumatol 1993;20:1425-8.

8 Mannik K. Harrison principle of internal medicine, 12th ed. New York: McGraw-Hill, 1991:1990. 


\title{
Symmetrical peripheral gangrene complicating Klebsiella pneumoniae sepsis associated with antiphospholipid antibodies
}

\author{
J-H Yoo, J-K Min, S-S Kwon, C H Jeong, W-S Shin
}

Ann Rheum Dis 2004;63:459-460. doi: 10.1136/ard.2003.012542

W have encountered a rare case of symmetrical peripheral gangrene ${ }^{1-5}$ complicating Klebsiella pneumoniae sepsis associated with antiphospholipid antibodies.

\section{CASE REPORT}

A 72 year old woman was admitted to our hospital with fever and symmetrical gangrene of both fingers and toes. She had been well until she began to suffer from fever and pain in the abdomen 3 days before admission. She then attended a local hospital and underwent an abdominal computed tomography scan that showed a liver abscess. Culture of blood and ultrasonography guided aspirates disclosed Klebsiella pneumoniae. The day before admission she had deep-bluish discolouration of both fingers and toes, and she was transferred to our hospital.

On admission, most of her fingers and toes already showed gangrenous changes (fig 1A), but the pulse in the bilateral radial, ulnar, and dorsalis pedis arteries was intact. Antithrombin III, protein C and S activities were depressed. IgG anticardiolipin antibody was highly positive, while IgM was negative (table 1 ). $\beta_{2}$-Glycoprotein I antibody was also positive. However, there was no evidence of lupus erythematosus by the criteria of the American College of Rheumatology. Computed tomography guided drainage of the liver abscess and culture of the aspirates subsequently disclosed $K$ pneumoniae. Third generation cephalosporin plus metronidazole were given. We initially considered fasciotomy, or even amputation, but the bilaterally intact arterial pulse and the fact that the gangrene was confined to the distal ends of the extremities made us hesitate to intervene surgically. Eventually, we decided to use an anticoagulant, in combination with vasodilators. Tissue plasminogen activator $5 \mathrm{mg} / \mathrm{h}$ was given for 16 hours. At the same time we began infusion of prostacyclin (epoprosterenol) $2 \mathrm{ng} / \mathrm{kg} / \mathrm{min}$ for 6 hours a day for 7 days. After 2 days of the tissue plasminogen activator schedule, low dose heparin was given over 5 days, followed by sodium warfarin $2.5 \mathrm{mg} /$ day until the international normalised ratio of 2.0-2.9 was reached. Low dose aspirin $325 \mathrm{mg}$ and nifedipine $30 \mathrm{mg}$ a day were also given. After the anticoagulant and vasodilator treatment had begun, none of the gangrenous lesions progressed any further, and the affected fingers and toes gradually began to regain warmth and colour. About six weeks later, most of the fingers and toes had returned to normal, and four necrotic distal toes of the right foot had been successfully amputated without further complication (fig 1B). As of May 2003, the patient is completely recovered, and now receiving rehabilitation treatment.
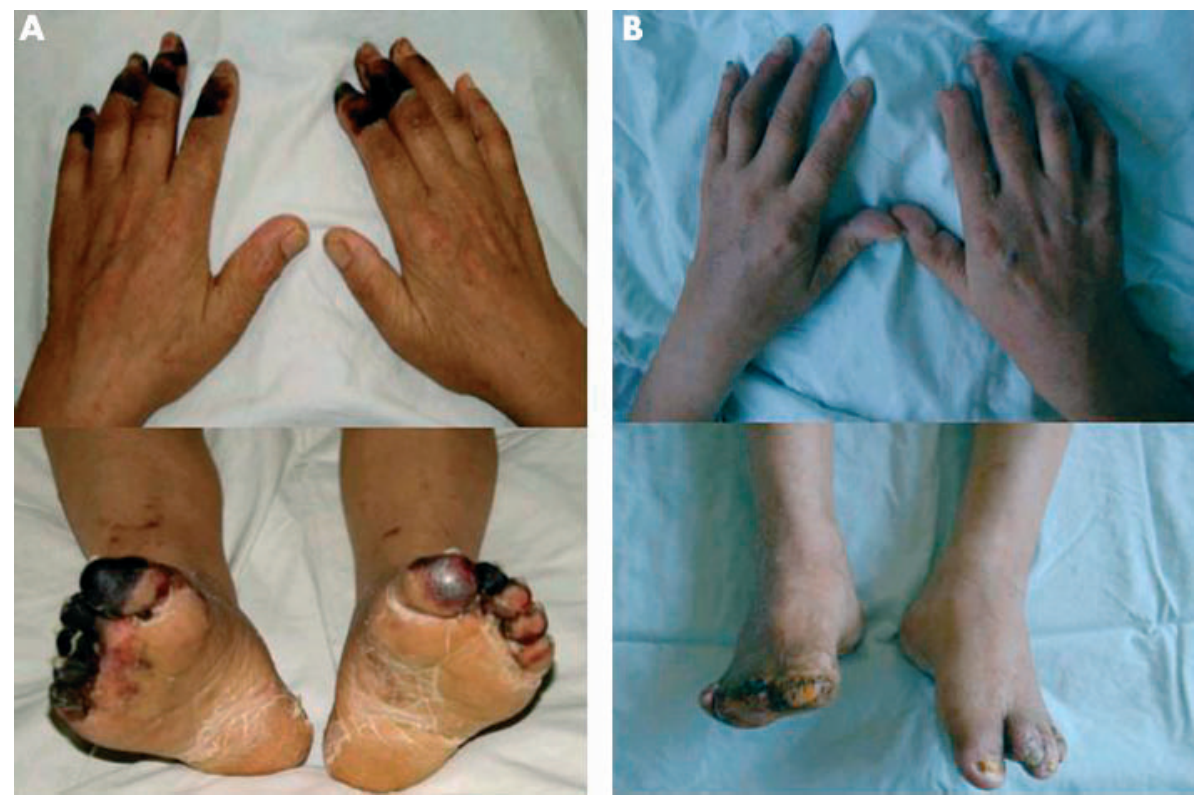

Figure 1 (A) Gangrene on fingers and toes on admission. (B) After anticoagulant and vasodilator treatment the fingers and most of the toes are back to normal, although the necrotic distal toes of the right foot have been amputated. 
Table 1 Laboratory parameters of the antiphospholipid syndrome

\begin{tabular}{llll}
\hline & $\begin{array}{l}\text { On } \\
\text { admission }\end{array}$ & $\begin{array}{l}\text { 6 Weeks } \\
\text { later }\end{array}$ & Convalescent \\
\hline IgG anticardiolipin antibody* & 87 & 27 & 7 \\
IgM anticardiolipin antibody & 8 & 3 & 4 \\
$\beta_{2}$-Glycoprotein I antibody & 31.0 & 11.0 & 11.0 \\
\hline
\end{tabular}

${ }^{*}$ Normal range of anticardiolipin antibody: 0-20; tnormal range of $\beta_{2}$ glycoprotein I antibody: $\leqslant 10 \mathrm{U} / \mathrm{ml}$.

\section{DISCUSSION}

Because $K$ pneumoniae was isolated from the blood, we concluded that hypercoagulability complicating K pneumoniae sepsis was the main cause of the clinical feature. We also recognised anticardiolipin and $\beta_{2}$-glycoprotein antibodies, suggesting that an immunological mechanism, such as catastrophic antiphospholipid syndrome, rather than an infection, might have played a role. ${ }^{15}$ IgG anticardiolipin antibody was still positive after 6 weeks $^{67}$ but became negative after convalescence ( 2 months later; table 1 ). On the basis of these findings, we postulate that both the positive anticardiolipin antibody and the K pneumoniae sepsis may be closely correlated with the gangrenous process. Although Amital et al reported that amputation could induce remission of the systemic illness, ${ }^{8}$ some reports have recommended that non-surgical management is preferable if there is an intact pulse in the affected limb. ${ }^{3}{ }^{4}$ The lesson we learnt from this case is that anticoagulant ${ }^{9}$ and/or vasodilator treatment, rather than surgical intervention, should be initiated as soon as possible for a septic patient with apparently symmetric gangrenous extremities.

Only sporadic reports of this rare disease entity have appeared until now, but there has been no report of a case complicating K pneumoniae sepsis. To our knowledge, this is the first report of catastrophic antiphospholipid syndrome following K pneumoniae sepsis.

\section{Authors' affiliations}

J-H Yoo, J-K Min, S-S Kwon, W-S Shin, Department of Internal

Medicine, Holy Family Hospital, The Catholic University of Korea,

College of Medicine, Seoul, Korea

C H Jeong, Department of Orthopaedic Surgery, Holy Family Hospital, The Catholic University of Korea, College of Medicine, Seoul, Korea

Correspondence to: Professor J-H Yoo, Department of Internal Medicine, Holy Family (Sung-Ka) Hospital, Sosa-2-Dong, Wonmi-Gu, Bucheon 420-717, Kyongki-Do, South Korea; mogulkor@medimail.co.kr

Accepted 26 July 2003

\section{REFERENCES}

1 Asherson RA. The catastrophic antiphospholipid syndrome. J Rheumatol 1992; 19:508-12.

2 Zulian F, Costantini C, Montesco MC, Schiavon F, Zacchello F. Successful treatment of gangrene in systemic necrotizing vasculitis with iloprost. Br J Rheumatol 1998;37:228-230.

3 Denning DW, Gilliland L, Hewlett A, Hughes LO, Reid CDL. Peripheral symmetrical gangrene successfully treated with epoprostenol and tissue plasminogen activator. Lancet 1986;ii:1401-2.

4 Hayem G, Kassis N, Nicaise P. Systemic lupus erythematosus associated with catastrophic antiphospholipid syndrome occurring after typhoid fever. A possible role of Salmonella lipopolysaccharide in the occurrence of diffuse vasculopathy - coagulopathy. Arthritis Rheum 1999;42:1056-61.

5 Asherson RA, Cervera R. Antiphospholipid antibodies and infections. Ann Rheum Dis 2003:62:388-93.

6 Brandt JT, Triplett DA, Alving B, Scharrer I. Criteria for the diagnosis of lupus anticoagulants: an update. Thromb Haemost 1995;74:1 185-90.

7 Levine JS, Branch DW, Rauch J. The antiphospholipid syndrome. NEngl J Med 2002;346:752-63.

8 Amital H, Levy Y, Davidson C, Lundberg I, Harju A, Kosach Y, et al. Catastrophic antiphospholipid syndrome: remission following leg amputation in 2 cases. Semin Arthritis Rheum 2001;31:127-32.

9 Uthman I, Taher A, Khalil I, Bizri AR, Gharavi AE. Catastrophic antiphospholipid syndrome associated with typhoid fever: comment on the article by Hayem et al. Arthritis Rheum 2002;46:850.

\section{An unusual case of ankle arthropathy}

\section{S Abraham, A Cope}

\section{CASE REPORT}

A 65 year old white woman presented with a 5 year history of pain and intermittent swelling of the left ankle. There had been no preceding trauma to the ankle and the symptoms were initially gradual in onset with aching and stiffness but then evolved into a continuous pain, particularly nocturnally. Her previous medical history included a right total hip replacement aged 53, menopause aged 53, and essential hypertension. There was no family history of rheumatological illness and her mother died of a myocardial infarction aged 56 years.

Examination disclosed evidence of osteoarthritis in her hands and an unusual symmetrical bony swelling of her lst and 2nd metacarpophalangeal joints. Her left ankle was swollen and warm to the touch (fig 1).

Investigations disclosed normal inflammatory markers and autoantibody screen, a mildly raised aspartate aminotransferase $35 \mathrm{U} / \mathrm{l}$ (normal $31 \mathrm{U} / \mathrm{l}$ ) and alanine aminotransferase $42 \mathrm{U} / \mathrm{l}$ (normal $30 \mathrm{U} / \mathrm{l}$ ), and a normal serum glucose. Radiographs of the ankle disclosed changes compatible with moderate to severe osteoarthritis, and those of the hands showed bilateral significant joint space narrowing, hooked osteophytes and sclerosis of the 2nd and 3rd metacarpophalangeal joints bilaterally, and chondrocalcinosis in the triangular ligament of the wrist. Her transferrin saturation index and ferritin were markedly raised at 98\% (normal 20-40) and $4340 \mu \mathrm{g} / \mathrm{l}$ (normal 12-200), respectively. Genotyping was

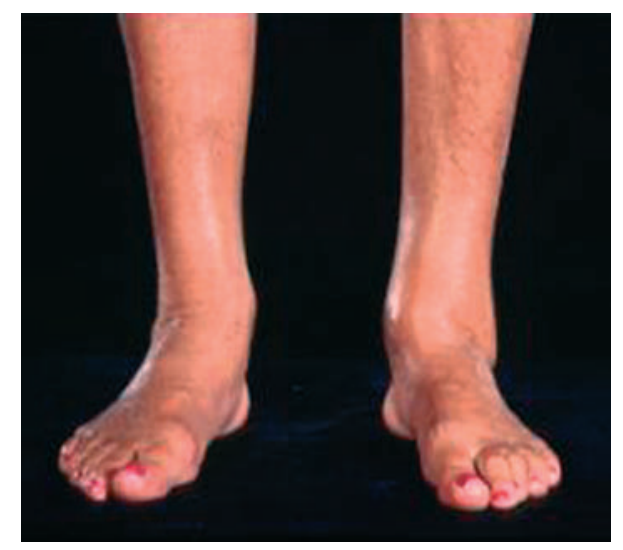

Figure 1 Left ankle demonstrating a palpable bony swelling. 


\begin{tabular}{|c|c|c|c|c|}
\hline Age (years) & Sex & $\begin{array}{l}\text { Diagnosis haemochromatosis } \\
\text { made before or after } \\
\text { arthropathy }\end{array}$ & Systemic manifestations & Reference \\
\hline 45 & $M$ & Before & Diabetes & Jacki et al $1999^{3}$ \\
\hline 57 & $\mathrm{~F}$ & After & No mention & Bailey et al $1998^{4}$ \\
\hline 75 & $M$ & After & No mention & Bailey et al $1998^{4}$ \\
\hline 53 & $M$ & No mention & No mention & Bailey et al $1998^{4}$ \\
\hline 65 & $\mathrm{~F}$ & After & Nil & Case presented \\
\hline
\end{tabular}

undertaken by polymerase chain reaction from genomic DNA. This showed the patient to be homozygous for the most common haemochromatosis mutation, cysteine to tyrosine $(\mathrm{C} 282 \mathrm{Y})$ on chromosome $6 .^{1}$

\section{DISCUSSION}

After the description of haemochromatosis in 1935, Schumacher first described an associated arthropathy in $1964 .{ }^{2}$ The prevalence of arthralgia and arthritis in haemochromatosis varies between 28 and $81 \%$. Characteristic radiological features have been reported in the hand, wrist, and hip. Involvement of the ankle joint seems to be rare and only four previous cases have been described, with only one presenting as ankle arthropathy ${ }^{3}{ }^{4}$ (table 1).

The arthropathy of haemochromatosis is usually degenerative and non-inflammatory, first affecting the small joints of the hands and then larger joints such as hips, shoulders, knees, and ankles. ${ }^{5}{ }^{6}$ The presentation of haemochromatosis may be confused with either rheumatoid arthritis or pseudogout. A polyarticular, symmetrical involvement, particularly of the 2nd and 3rd metacarpophalangeal joints, in association with other superficial bony swellings consistent with osteoarthritis should alert the clinician to the possibility of haemochromatosis. Acute attacks of synovitis in such patients can be secondary to calcium pyrophosphate dihydrate deposition. Despite treatment of haemochromatosis with phlebotomy, the arthropathy seldom improves.

To date, a number of theories have been reported to explain the relationship between haemochromatosis and arthropathy. Ferric salts are found to promote the formation and deposition of intra-articular calcium pyrophosphate crystals by inhibiting the activity of synovial pyrophosphatase, and hence can precipitate attacks of pseudogout in the joint. It has also been proposed that there is a metabolic abnormality independent of the primary iron absorption disorder which can disrupt the configuration of the cartilage matrix, leading to premature osteoarthritis.

This case report identifies only the second reported case of haemochromatosis presenting as an ankle arthropathy. This diagnosis should always be considered in the differential diagnosis of an arthropathy in unusual joint sites. Screening tests, such as measurements of iron metabolism, should be performed, followed by, if indicated, the diagnostic genomic DNA analysis for the mutations found in haemochromatosis. The importance of making a correct diagnosis is that effective treatment by phlebotomy can halt progression of the systemic effects of excess iron deposition and progression to resultant damage of internal organs. After a diagnosis of haemochromatosis is made, all close relatives (including parents, siblings, and all offspring) should be genetically tested for the presence of haemochromatosis mutations. Early diagnosis and treatment of family members with the disease is essential to prevent end-organ damage, which might include cardiomyopathy, diabetes, liver cirrhosis, and hepatocellular carcinoma.

\section{Authors' affiliations}

S Abraham, A Cope, The Kennedy Institute of Rheumatology, Faculty of Medicine, Imperial College, 1 Aspenlea Road, Hammersmith, London W6 8LH, UK

Correspondence to: Dr S M Abraham; s.abraham@ic.ac.uk

Accepted 29 June 2003

\section{REFERENCES}

1 Feder JN, Gnirke A, Thomas W. A novel MHC class 1 like gene is mutated in patients with hereditary haemochromatosis. Nature Genetics 1996;13:399-408.

2 Schumacher HR Jr. Haemochromatosis and arthritis. Arthritis Rheum 1964;26:41-50.

3 Jacki SH, Uhl M, Adler CP, Peter HH, Kempis J. Predominant ankle arthropathy in hereditary haemochromatosis. Rheumatology (Oxford) 1999;38:378-9.

4 Bailey EJ, Gardner BA. Hemochromatosis of the foot and ankle: report of three cases and review of the literature. Clin Orthop 1998;349:108-15.

5 Dymock IW, Hamilton EDB, Laws JW, Williams R. Arthropathy of hemochromatosis. Clinical and radiological analysis of 63 patients with iron overload. Ann Rheum Dis 1970;29:469-76.

6 Faraawi R, Harth M, Kertesz A, Bell D. Arthritis in hemochromatosis. J Rheumatol 1993;20:448-52. 


\title{
Does etanercept monotherapy enhance the risk of Listeria monocytogenes meningitis?
}

\author{
P Pagliano, V Attanasio, U Fusco, D A Mohamed, M Rossi, F S Faella
}

$C^{\alpha}$ onsiderable data have identified tumour necrosis factor $\alpha(\mathrm{TNF} \alpha)$ as a pivotal mediator in inflammatory processes, suggesting that it has a role also in the pathogenesis of some autoimmune diseases, such as rheumatoid arthritis (RA). ${ }^{12}$ Currently, two drugs that interfere with TNF $\alpha$, infliximab and etanercept, have been extensively used for the treatment of patients with RA and other immunological disorders; both have been associated with a higher risk of serious infective complications. ${ }^{3-7}$

Listeria monocytogenes is a Gram positive intracellular organism seen almost always in neonatal sepsis, elderly meningitis, and in patients with chronic diseases and impairment of cellular immunity, which avoids the host immunity by a mechanism of cell to cell spreading. ${ }^{8}$

Association between anti-TNF $\alpha$ agents and listeriosis has already been reported in patients treated with other immunosuppressive agents, but not in patients receiving etanercept monotherapy. ${ }^{9} 10$

\section{CASE REPORT}

We report a case of Listeria meningitis in a 45 year old patient with RA. Methotrexate and cyclophosphamide had been given until 20 months before admission to hospital, when low grade renal failure developed and treatment was changed to monotherapy with etanercept $25 \mathrm{mg}$ twice weekly. One day before admission, fever, malaise, headache, and progressive confusion developed.

At entry, examination showed a comatose state, neck stiffness, and fever $\left(38.7^{\circ} \mathrm{C}\right)$. Deep tendon reflexes were symmetric, plantar responses were flexor. The findings on a computed tomographic scan of the brain were unremarkable. Blood laboratory analysis showed white blood cells $15 \times 10^{9} / 1$ (91\% neutrophils), glucose $8.3 \mathrm{mmol} / \mathrm{l}$, blood urea nitrogen $17.5 \mathrm{mmol} / \mathrm{l}$ of urea, creatinine $180 \mu \mathrm{mol} / \mathrm{l}$, and no other significant abnormalities. Cerebrospinal fluid (CSF) showed pleocytosis $\left(1.2 \times 10^{9}\right.$ cells/l, lymphocyte $\left.43 \%\right)$, high protein content $(2.50 \mathrm{~g} / \mathrm{l})$, and glucose $3.6 \mathrm{mmol} / \mathrm{l}$. Etanercept was withdrawn, and treatment with intravenous ceftriaxone ( $3 \mathrm{~g} /$ day), ampicillin (12 g/day), and dexamethasone ( $16 \mathrm{mg} /$ day $)$ was begun. Further results of the blood analysis obtained on

Table 1 T cell subset, TNF $\alpha$, and inflammatory index levels during the follow up

\begin{tabular}{lcc}
\hline Variable & $\begin{array}{l}\text { 30th Follow up } \\
\text { day }\end{array}$ & $\begin{array}{l}\text { 90th Follow up } \\
\text { day }\end{array}$ \\
\hline CD4+ lymphocyte $\left(\times 10^{9}\right.$ cells/l) & 1.41 & 1.87 \\
CD4+/CD7+ (\%) & 92 & 95 \\
CD8+ lymphocyte $\left(\times 10^{9}\right.$ cells/l) & 0.47 & 0.98 \\
CD8+/CD38+ (\%) & 36 & 39 \\
$\mathrm{TNF} \alpha(\mathrm{ng} / \mathrm{\mu l})$ & 157 & 162 \\
$\mathrm{CRP}(\mathrm{mg} / \mathrm{l})$ & 8 & 2 \\
ESR (mm/1 st h) & 40 & 25 \\
\hline & &
\end{tabular}

the second day of hospitalisation showed an erythrocyte sedimentation rate (ESR) of $42 \mathrm{~mm} / \mathrm{lst} \mathrm{h}, \mathrm{C}$ reactive protein (CRP) $411 \mathrm{mg} / \mathrm{l}, \mathrm{CD} 4+$ cell count $1.41 \times 10^{9} / 1\left(\mathrm{CD}^{+} / \mathrm{CD}^{+}\right.$ $92 \%), \mathrm{CD}^{+}$cell count $0.47 \times 10^{9} / 1\left(\mathrm{CD}^{+} / \mathrm{CD} 38^{+} 42 \%\right), \mathrm{TNF} \alpha$ $32.9 \mathrm{ng} / \mathrm{ml}$. On the fourth day, Listeria monocytogenes grew from CSF and blood cultures, ceftriaxone was discontinued, and dexamethasone slowly tapered.

During the next 4 days, the patient's symptoms improved. Ampicillin was given for a total of 28 days, when full normalisation of the CSF variables had occurred. Blood analysis 2 and 4 months after meningitis, while the patient was taking only mild dose of prednisone $(40 \mathrm{mg} /$ day $)$, showed a reduction of the ESR and CRP levels and a rise in TNF $\alpha$ (table 1).

\section{DISCUSSION}

The main concern about treatment of RA with TNF $\alpha$ neutralising agents is the possibility that latent tuberculosis may be unmasked; subsequent reports disclosed an increase in susceptibility for all infections sustained by intracellular agents. Infliximab, whose use is recommended in association with other immunosuppressive drugs, is implicated in the vast majority of cases. ${ }^{67}$ To our knowledge, etanercept has been associated with Listeria monocytogenes meningitis only in a 72 year old patient with RA receiving multiple immunosuppressive treatment (etanercept, prednisone, and methotrexate), and no case has been seen during monotherapy. ${ }^{9} \mathrm{~A}$ study of our patient's lymphocyte subset showed that it did not change during the course of the disease. TNF $\alpha$ levels increased during the follow up, when etanercept was discontinued. Although there is no evidence about association between low TNF $\alpha$ levels and immunosuppression, in our case we suggest there may be an association between etanercept treatment and impairment of cell mediated immunity because of low $\mathrm{TNF} \alpha$ circulating levels.

Screening before treatment for latent tuberculosis, close clinical evaluation of every febrile illness, and zero tolerance regimens against Listeria and other intracellular preventable pathogens may improve the long term outcome of patients treated with anti-TNF $\alpha$ agents.

\section{Authors' affiliations}

P Pagliano, V Attanasio, U Fusco, D A Mohamed, M Rossi, F S Faella, Department of Emergency, Division of Infectious Neuropathies, "D. Cotugno" Hospital, Naples, Italy

Correspondence to: Dr P Pagliano, D Cotugno Hospital, Via G Quagliariello 54, 80131, Naples, Italy; ppagliano@libero.it

Accepted 17 December 2003

\section{REFERENCES}

1 Feldman M, Taylor P, Paleolog E, Brennan FM, Maini RN. Anti-TNF alpha therapy is useful in rheumatoid arthritis and Crohn's disease: analysis of the mechanisms of action predicts utility in other diseases. Transplant Proc 1998;30:4126-7. 
2 Song XR, Fox F, Gallo MA, Rosenberg A, Jordan R, Shealy D, et al. Effects of 2 different anti-Tumor necrosis factor- $\alpha$ in a primate model of subcutaneous abscess formation. J Infect Dis 2002;185:204-13.

3 Moreland L, Cohen S, Baumgartner E, Tindall EA, Bulpitt K, Martin R, et al. Longterm safety and efficacy of etanercept in patients with rheumatoid arthritis. J Rheumatol 2001;28:1238-44.

4 Weinblatt ME, Kremer JM, Bankhurst AD, Bulpitt KJ, Fleischmann RM, Fox RI, et al. A trial of etanercept, a recombinant tumor necrosis factor receptor: $\mathrm{Fc}$ fusion protein in patients with rheumatoid arthritis receiving methotrexate. N Engl J Med 1999;340:253-9.

5 Kroesen S, Widmer AF, Tyndall A, Hasler P. Serious bacterial infections in patients with rheumatoid arthritis under anti-TNF- $\alpha$ therapy. Rheumatology (Oxford) 2003:42:617-21.
6 Doran MF, Crowson CS, Pond GR, O'Fallon WM, Gabriel SE. Frequency of infection in patients with rheumatoid arthritis compared with controls: a population-based study. Arthritis Rheum 2002;46:2287-93.

7 Keane J, Gershon S, Wise RP, Mirabile-Levens E, Kasznica J, Schwieterman WD, et al. Tuberculosis associated with infliximab, a tumor necrosis factor alpha-neutralising agent. N Engl J Med 2001;345:1098-104.

8 Lorber B. Listeriosis. Clin Infect Dis 1997;24:1-1 1 .

9 Slifman NR, Gershon SK, Lee JH, Edwards ET, Braun MM. Listeria monocytogenes infection as a complication of treatment with tumor necrosis factor $\alpha$-neutralizing agent. Arthritis Rheum 2003;48:319-24

10 Gluck T, Linde H-J, Scholmerich J, Muller-Ladner U, Fiehn C, Bohland P. Antitumor necrosis factor and Listeria monocytogenes infection: report of two cases. Arthritis Rheum 2002;46:2255-7.

\title{
Autoantibodies against glucose-6-phosphate isomerase are not a diagnostic marker for juvenile idiopathic arthritis
}

\author{
A Schmitt, D Schubert, C Sengler, T Kamradt
}

$\mathrm{R}$ heumatoid arthritis (RA) and juvenile idiopathic arthritis (JIA) are chronic inflammatory diseases that primarily affect the joints. The triggers that activate autoreactive $\mathrm{T}$ and $\mathrm{B}$ lymphocytes in arthritic patients are still unknown. ${ }^{1}$ It has been widely assumed, however, that the autoantigens recognised by arthritogenic lymphocytes are joint-specific. This assumption has been challenged by findings from a murine model of spontaneously developing polyarthritis. There, a ubiquitously expressed soluble antigen, the glycolytic enzyme glucose-6-phosphate isomerase (GPI)

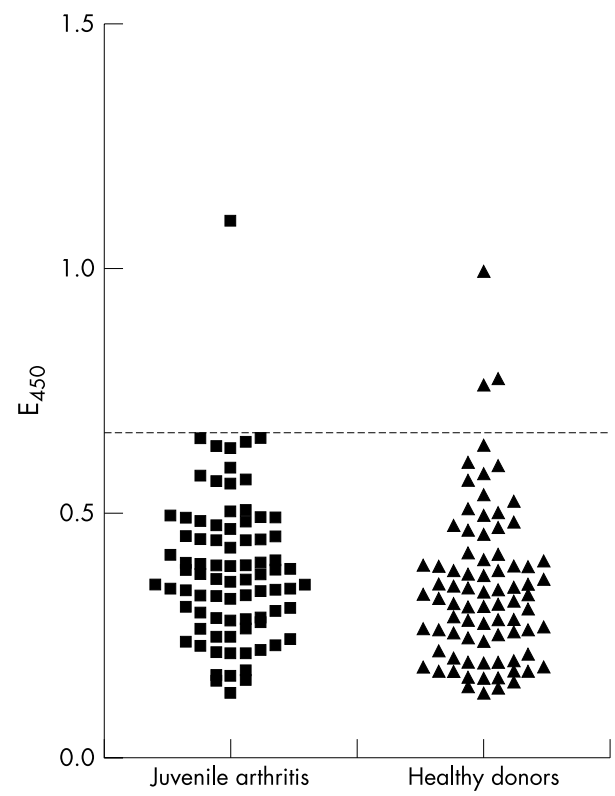

Figure 1 Plasma from patients with JIA or controls rarely contain antibodies against recombinant human GPI. Enzyme linked immunosorbent assays (ELISAs) were performed on sera (diluted 1:50) from 82 patients with JIA or 81 controls matched for age to detect antibodies against recombinant human GPI (produced in E coli in our laboratory). The cut off point for a positive value was defined as two standard deviations above the mean optical density of the 81 samples from healthy donors (dotted line). is the target of autoreactive $\mathrm{T}$ cells and arthritogenic antibodies. ${ }^{2}$

It is, therefore, important to determine if GPI is also relevant to human arthritides. A role for antibodies against GPI in the pathogenesis of RA has been claimed ${ }^{3}$ and refuted ${ }^{4-7}$ Some characteristics of the murine model, such as the lack of rheumatoid factors, resemble JIA rather than RA. Therefore, we tested whether plasma from patients with JIA contained antibodies against GPI. Recombinant human GPI was expressed as described ${ }^{4}$ and used to test serial dilutions of plasma from patients with JIA or controls matched for age. At a dilution of 1:50, only 1/82 JIA samples and 3/81 controls bound recombinant human GPI (fig 1). Thus, although autoantibodies specific for GPI mediate polyarthritis in a murine model, such antibodies do not occur in a significant fraction of patients with RA or JIA.

\section{Authors' affiliations}

A Schmitt, D Schubert, T Kamradt, Deutsches

Rheumaforschungszentrum Berlin, 10117 Berlin, Germany

C Sengler, Universitätsklinikum Charité, Department of Paediatrics,

10098 Berlin, Germany

Correspondence to: $\operatorname{Dr} T$ Kamradt, Deutsches

Rheumaforschungszentrum, Schumannstr 20/21, 10117 Berlin,

Germany; Kamradt@drfz.de

Accepted 28 July 2003

\section{REFERENCES}

1 Kamradt T, Mitchison NA. Advances in immunology: tolerance and autoimmunity. N Engl J Med 2001;344:655-64.

2 Matsumoto I, Staub A, Benoist C, Mathis D. Arthritis provoked by linked T and B cell recognition of a glycolytic enzyme. Science 1999;286:1732-5.

3 Schaller M, Burton DR, Ditzel HJ. Autoantibodies to GPI in rheumatoid arthritis: linkage between an animal model and human disease. Nat Immunol $2001 ; 2: 746-53$.

4 Schubert D, Schmidt M, Zaiss D, Jungblut PR, Kamradt T. Autoantibodies against GPI and creatine kinase in rheumatoid arthritis. Nat Immunol 2002;3:411.

5 Kassahn D, Kolb C, Solomon S, Bochtler P, Illges $H$. Few human autoimmune sera detect GPI. Nat Immunol 2002;3:411-12.

6 Matsumoto I, Lee DM, Goldbach-Mansky R, Sumida T, Hitchon CA, Schur PH, et al. Low prevalence of antibodies to glucose-6-phosphate isomerase in patients with rheumatoid arthritis and a spectrum of other chronic autoimmune disorders. Arthritis Rheum 2003;48:944-54.

7 Herve CA, Wait R, Venables PJ. Glucose-6-phosphate isomerase is not a specific autoantigen in rheumatoid arthritis. Rheumatology (Oxford) 2003;8:986-8. 


\title{
Haemorrhagic myositis associated with prophylactic heparin use in dermatomyositis
}

\author{
D M Langguth, R C W Wong, C Archibald, P G Hogan
}

Ann Rheum Dis 2004;63:464-465. doi: 10.1136/ard.2003.010272

A n 80 year old man was admitted with a short history of fever, dyspnoea, and productive cough. A chest radiograph disclosed right lower lobe infiltrates, and a diagnosis of community acquired pneumonia was made. However, it was noted that he had profound weakness of the proximal, respiratory, and bulbar muscles together with typical features of dermatomyositis, including periorbital oedema and heliotrope discolouration, nailfold infarcts, and Gottron's papules. The serum creatine kinase (CK) level was raised at 1850 IU (reference range $<300$ IU). An electromyogram and muscle biopsy of the left vastus lateralis confirmed inflammatory myositis. There was no excess bleeding at the site. The diagnosis was revised to aspiration pneumonia secondary to bulbar weakness associated with dermatomyositis. Respiratory muscle weakness progressed after admission, with a fall in the forced expiratory volume ( 1 second) to 0.95 litres (predicted $=2.5$ litres).

Intravenous methylprednisolone (500 mg/day for 3 days) was given, followed by oral prednisone at $80 \mathrm{mg} /$ day. Treatment with prophylactic unfractionated heparin (UFH) (5000 IU twice a day subcutaneously) was started (the patient's weight was $80 \mathrm{~kg}$ ).

After 9 days of corticosteroid treatment, the patient's strength and serum CK levels were improving. However, on day 10 he complained of a painful right hip of gradual onset. Plain radiographs of the right hip were normal. Avascular necrosis was suspected and magnetic resonance imaging (MRI) of the region was arranged for the next day. Examination before MRI showed a palpable small mass in the left rectus sheath, a tense swollen right thigh, and extensive bruising affecting the left flank. MRI subsequently showed extensive haemorrhagic change in the muscles of the right thigh (fig 1), and computed tomography of the

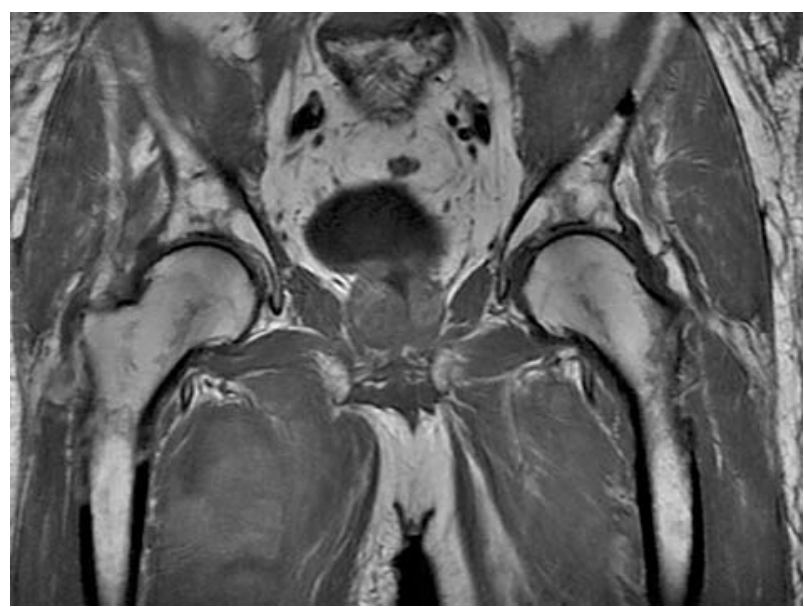

Figure 1 MRI of the pelvis disclosing a large right thigh haematoma. abdomen showed haemorrhage in the rectus sheath and oblique muscles (fig 2). His haemoglobin had fallen to $50 \mathrm{~g} / \mathrm{l}$ from $130 \mathrm{~g} / \mathrm{l}$ overnight, platelets were within the reference range, and the activated partial thromboplastin time (APTT) was slightly raised at 42 seconds (reference range $<38$ seconds). The APTT, prothrombin, and bleeding time were normal before the muscle biopsy.

The subcutaneous heparin was stopped and 3 units of packed cells and 4 units of fresh frozen plasma were transfused. The patient subsequently developed pulmonary oedema requiring assisted ventilation, but made a successful recovery and returned home after a short period of intensive rehabilitation. There was no history suggestive of a coagulation disorder and after the transfusion his coagulation profile returned to normal.

\section{DISCUSSION}

Our patient had a major complication associated with standard dose UFH use for deep vein thrombosis prophylaxis. Significant muscle haemorrhage has not been previously reported in patients with myositis, though recently has been found in a patient receiving therapeutic low molecular weight heparin (LMWH) and warfarin. ${ }^{1}$ Heparin treatment is known to be associated with an increased risk of major bleeding, about $0.3 \%,{ }^{2}$ with both UFH and LMWH, mostly occurring in the gastrointestinal tract, though haemorrhage at the site of injection has been reported. ${ }^{3}$

Given the serious nature of this event, we would advise caution in using prophylactic heparin in patients with acute myositis.

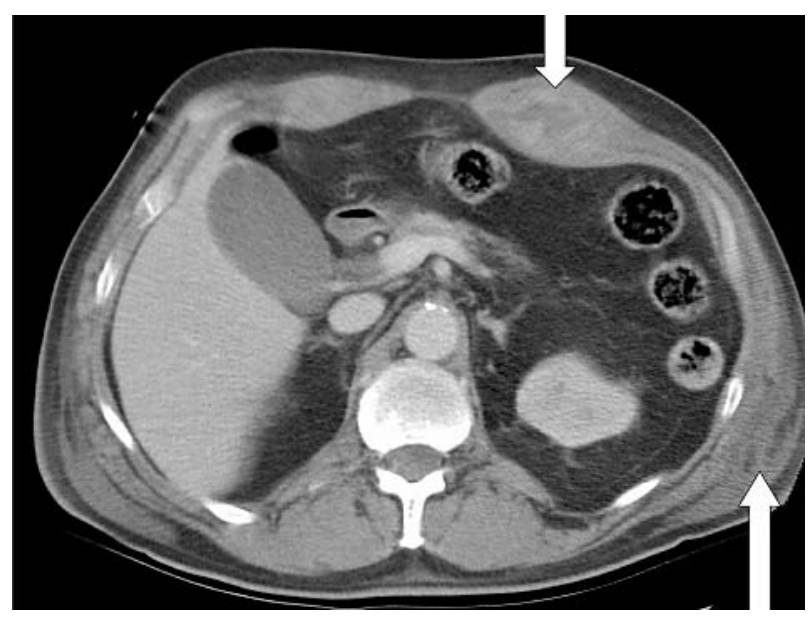

Figure 2 A computed tomographic scan of the abdomen showing left rectus abdominus and oblique musculature haemorrhage. 

Authors' affiliations
D M Langguth, R C W Wong, C Archibald, P G Hogan, Departments of
Clinical Immunology and Radiology, Princess Alexandra Hospital, Perth, Australia

Correspondence to: $\operatorname{Dr} D$ M Langguth, Immunology Department, Royal Perth Hospital, Wellington St, Perth, WA 6000, Australia;

daman.langguth@health.wa.gov.au

Accepted 30 June 2003

\section{REFERENCES}

1 Gutknecht DR. Hematoma of the rectus sheath. N Engl J Med 2003;348:15.

2 Kleber FX, Witt C, Vogel G, Koppenhagen K, Schomaker U, Flosbach CW. Randomized comparison of enoxaparin with unfractionated heparin for the prevention of venous thromboembolism in medical patients with heart failure or severe respiratory disease. Am Heart $J$ 2003; 145:614-21

3 Antonelli D, Fares L, Annene C. Enoxaparin associated with huge abdominal wall hematomas: a report of two cases. Am Surg 2000;66:797-800.

\section{Isolated cranial nerve syndromes without proximal carotid involvement in aortoarteritis}

\section{G R Shroff, D R Karnad, U S Limaye, V M Kothari}

$\mathrm{T}$ akayasu's arteritis or aortoarteritis affects the aorta and its proximal branches. ${ }^{1}$ Cranial nerve involvement in the form of ischaemic optic neuropathy secondary to proximal carotid involvement is common. ${ }^{2}$ Involvement of other cranial nerves has been reported only once before. ${ }^{3}$ We report two patients with aortoarteritis who developed isolated cranial nerve palsies. Notably, in both cases it occurred without proximal carotid involvement.

\section{CASE REPORTS}

Patient 1, a 30 year old businessman, presented with malignant hypertension because of right renal artery stenosis due to aortoarteritis affecting the abdominal aorta. After successful balloon angioplasty, blood pressure was well controlled with antihypertensive drugs. Two years later he developed sudden headache and diplopia on looking towards the left. Examination showed a convergent squint in the left eye due to abducens nerve palsy. Contrast enhanced brain computed tomography (CT) scan and cerebrospinal fluid (CSF) analysis were normal. Angiography showed that the aortic arch and its branches were normal; the suprarenal abdominal aorta showed irregular narrowing with stenosis of the left renal artery and the previously balloon-dilated right renal artery. On treatment with $1 \mathrm{mg} / \mathrm{kg} /$ day of prednisolone he recovered completely in 10 days.

One year later he developed diplopia again. This time he was found to have right abducens nerve palsy. Angiography showed normal carotid vessels but complete occlusion of the left subclavian artery $1 \mathrm{~cm}$ distal to its origin. Again, he made a complete recovery with $1 \mathrm{mg} / \mathrm{kg}$ of prednisolone over 20 days.

Patient 2, an 18 year old female student, was admitted for accelerated hypertension. A renal Doppler examination showed left renal artery stenosis. On aortography she had an irregular contour with narrowing of the abdominal aorta and occlusion from the origin of the left renal artery, suggestive of aortoarteritis. She refused renal angioplasty and was treated with antihypertensive drugs. Four years later she developed sudden diplopia and right eyelid ptosis. Examination showed complete ptosis on the right, divergent squint, and ophthalmoplegia, suggestive of isolated right oculomotor palsy. The pupil, however, was normal in size and constricted briskly in light. Contrast enhanced brain CT scan, CSF analysis, and four-vessel angiogram were normal. She received $1 \mathrm{mg} / \mathrm{kg}$ of prednisolone for 30 days with complete recovery.

\section{DISCUSSION}

Both patients satisfied Ishikawa's diagnostic criteria for aortoarteritis, ${ }^{4}$ and presented with sudden onset of isolated cranial nerve palsies. The normal CT scans and CSF examination excluded structural and infective aetiologies of cranial nerve palsies. The sudden onset of deficits in both patients suggested a vascular cause. Moreover, recurrence of the cranial nerve deficit on the contralateral side in patient 1 and the presence of pupillary sparing in patient 2 further supported a vascular aetiology. The pupil is characteristically unaffected in ischaemic oculomotor nerve palsy because the pupillary fibres, which are outermost, receive additional blood supply from the pial (meningeal) vessels and are therefore spared in oculomotor nerve infarction. ${ }^{5}$

The oculomotor and abducens nerves derive their arterial supply from the inferolateral trunk, which originates from the intracavernous siphon of the internal carotid artery. ${ }^{6}$ In our patients the extracranial carotid circulation and the siphon of the internal carotid artery were angiographically normal, suggesting involvement of small sized vessels supplying the cranial nerves. Nuclear brainstem infarcts could also cause cranial nerve deficits ${ }^{7}$ and a magnetic resonance imaging study (not done in our patients) would be most sensitive to diagnose them. However, this is very unlikely owing to the absence of signs of involvement of the brainstem ascending or descending tracts and rapid complete recovery of deficits with corticosteroids.

Similar isolated palsies of the nerves innervating the extraocular muscles may occur in other vasculitides, including Behçet's disease and giant cell arteritis. ${ }^{89}$

Small vessel involvement has been described in some patients with aortoarteritis. Manifestations of these include glomerulonephritis, ${ }^{10}$ interstitial lung disease, ${ }^{11}$ and necrotising vasculitic lesions of the skin. ${ }^{12}$ It is likely that cranial nerve palsies in our patients too might be due to similar small vessel involvement in the central nervous system.

\section{Authors' affiliations \\ G R Shroff, D R Karnad, U S Limaye, V M Kothari, Departments of Medicine and Radiology, Seth G S Medical College and K E M Hospital, Mumbai, India}

Correspondence to: $\operatorname{Dr}$ G R Shroff, Department of Internal Medicine, Hennepin Country Medical Center, Minneapolis, MN 55415, USA; drgautamshroff@hotmail.com

Accepted 10 July 2002 


\section{REFERENCES}

1 Jennette JC, Falk RJ, Andrassy K, Bacon PA, Churg J, Gross WL, et al. Nomenclature of systemic vasculitides: proposal of an international consensus conference. Arthritis Rheum 1994;37:187-92.

2 Schmidt MH, Fox AJ, Nicolle DA. Bilateral anterior ischaemic optic neuropathy as a presentation of Takayasu's disease. J Neuroophthalmol 1997;17:156-61.

3 Gupta R, Kumar S. Relapsing spinal cord and cranial nerve syndromes in Takayasu's arteritis. J Assoc Physicians India 1989;37:537-9.

4 Ishikawa K. Diagnostic approach and proposed criteria for the clinical diagnosis of Takayasu's arteriopathy. J Am Coll Cardiol 1998;12:964.

5 Rosenstein ED, Sobelman J, Kramer N. Isolated, pupil-sparing third nerve palsy as initial manifestation of systemic lupus erythematosus. J Clin Neuroophthalmol 1989:9:285-8.

6 Lapresle J, Lasjaunias P. Cranial nerve ischaemic arterial syndromes. Brain 1986;109:207-15.
7 Thomke F, Gutmann L, Stoeter P, Hopf HC. Cerebrovascular brainstem diseases with isolated cranial nerve palsies. Cerebrovasc Dis 2002; 13:147-55

8 Lew H, Lee JB, Han SH, Kim HS, Kim SK. Neuro-Behçet's disease presenting with isolated unilateral lateral rectus muscle palsy. Yonsei Med J 1999:40:294-6.

9 Goldberg RT. Ocular muscle paresis and cranial arteritis-an unusual case. Ann Ophthalmol 1983;15:240-3.

10 Yoshikawa Y, Truong LD, Mattioli CA, Lederer E. Membranoproliferative glomerulonephritis in Takayasu's arteritis. Am J Nephrol 1988;8:240-4.

11 Greene NB, Baughman RP, Kim CK. Takayasu's arteritis associated with interstitial lung disease and glomerulonephritis. Chest 1986;89:605-6.

12 Mousa AR, Marafie AA, Dajani Al. Cutaneous necrotizing vasculitis complicating Takayasu's arteritis with a review of cutaneous manifestations. J Rheumatol 1985; 12:607-10.

\title{
Myeloablative immunosuppressive treatment with autologous haematopoietic stem cell transplantation in a patient with psoriatic arthropathy and monoclonal gammopathy of undetermined significance
}

\author{
M Mohren, T Daikeler, D Benz, I Günaydin, L Kanz, I Kötter
}

$\mathrm{T}$ ransplantation of peripheral blood stem cells (PBSCT) is currently explored in patients with refractory autoimmune diseases, ${ }^{12}$ and results so far show that about two thirds of patients who receive a transplant benefit from this procedure. ${ }^{3}$ Transplant related mortality in patients with autoimmune disease is similar to that seen in patients with non-Hodgkin's lymphoma. ${ }^{4}$

\section{CASE REPORT}

We report on a 34 year old male patient with a 16 year history of psoriatic arthropathy with mutilating bilateral lesions of the wrists, metacarpal, proximal and distal interphalangeal and metatarsal, and lower extremity interphalangeal joints, who was refractory to treatment with multiple disease modifying, immunosuppressive substances, including gold, methotrexate (MTX), MTX plus sulfasalazine, cyclosporin A (CSA), mycophenolate mofetil (MMF) alone or in combination with CSA, steroids, and a combination of CSA, MTX, and MMF. IgA $\kappa$ monoclonal gammopathy of unknown significance developed later in the course of the disease without evidence for either multiple myeloma or systemic amyloidosis. Treatment of arthritis with a non-steroidal anti-inflammatory drug (NSAID) was complicated by a duodenal ulcer. There were only modest psoriatic skin lesions affecting the extensor surfaces of both knees and elbows.

PBSCT was considered in this patient, because tumour necrosis factor $\alpha$ antagonists had not yet been licensed for use in psoriatic arthropathy at that time. We were particularly concerned about the presence of the IgA $\kappa$ paraprotein, so therapeutic strategies to control symptoms of arthritis also aimed at eliminating the potentially hazardous plasma cell clone. Haematopoietic stem cells were mobilised with cyclophosphamide (Cy) $4000 \mathrm{mg} / \mathrm{m}^{2}$ and granulocyte-colony stimulating factor (G-CSF) $5 \mu \mathrm{g} / \mathrm{kg}$. Stem cell apheresis was performed following standard procedures, and T cell depletion of the graft was achieved by CD $34+$ selection using the CliniMACS device. CD $34+$ cells $\left(11.38 \times 10^{6}\right.$ cells $\left./ \mathrm{kg}\right)$ were harvested. Myeloablative immunosuppression consisted of Cy $200 \mathrm{mg} / \mathrm{kg}$ ( $50 \mathrm{mg} / \mathrm{kg} / \mathrm{day}$, days -5 to -2$)$, and in vivo T cell depletion was achieved with antithymocyte globulin (ATG) (Fresenius) $80 \mathrm{mg} / \mathrm{kg}(20 \mathrm{mg} / \mathrm{kg} /$ day, days -4 to -1$)$. CD $34+$ cells $\left(5.21 \times 10^{6}\right.$ cells $\left./ \mathrm{kg}\right)$ were retransfused on day 0 . An acute flare of arthritis occurred while the patient was receiving GCSF for stem cell mobilisation, and this was symptomatically treated with an NSAID. Pancytopenia after myeloablative treatment was complicated by neutropenic fever $\left(39.1^{\circ} \mathrm{C}\right)$ on day 11 , subsiding under standard antibiotic treatment. Mucositis and diarrhoea WHO grade I occurred, lasting for 3 days. Within 3 days after the start of high dose Cy the symptoms of arthritis completely disappeared, as did the psoriatic lesions. As granulocytes did not recover by day 15 , G-CSF was started, and no new flare of arthritis was observed. Granulocytes were $>10^{9} / \mathrm{l}$ by day 19 , platelets $>20 \times 10^{9} / 1$ by day 21 , and the erythrocyte sedimentation rate and $C$ reactive protein subsequently normalised.

Clinical findings were confirmed by negative bone scintigraphy on day 21 . Within 6 months after PBSCT the IgA $\kappa$ paraprotein disappeared.

However, 16 months after PBSCT, polyarthritis recurred, although without laboratory evidence of systemic inflammation (erythrocyte sedimentation rate and $\mathrm{C}$ reactive protein were within normal limits), apparently now following a more benign course. At present, the patient is receiving low dose MTX ( $10 \mathrm{mg} /$ week) and a COX-2 selective NSAID (celecoxib) and has only mild signs of arthritis of the right wrist. Monoclonal gammopathy has not reappeared.

\section{DISCUSSION}

To our knowledge this is the first report of PBSCT in a patient with psoriatic arthropathy. In rheumatoid arthritis, disease activity decreased markedly in 8 of 12 patients, with patients free from disease modifying antirheumatic drug treatment for a period of 130 days during a 7-21 month follow up after PBSCT. ${ }^{5}$ Remission of arthritis in patients with rheumatoid arthritis after PBSCT usually lasts for 6-9 months..$^{5-7}$ In our patient relapse of arthritis, with a now more benign course, did not occur until 16 months after PBSCT, possibly owing to a more aggressive immunosuppressive regimen, including in 
vivo T cell depletion with ATG and graft manipulation. Three patients with remission of psoriasis (without arthropathy) after PBSCT due to a haematological disease relapsed within 6-14 months as described in a previously published report. ${ }^{8}$ However, skin involvement was not of major concern in our patient.

We conclude that it may be worth exploring PBSCT further in young patients with mutilating psoriatic arthropathy who are resistant to disease modifying antirheumatic drugs and for whom tumour necrosis factor $\alpha$ antagonist treatment has failed.

\section{Authors' affiliations}

M Mohren, T Daikeler, D Benz, I Günaydin, L Kanz, I Kötter, Department of Haematology, Oncology, Immunology and

Rheumatology, Tübingen University Hospital, Tübingen, Germany

Correspondence to: Dr I Kötter, Department of Internal Medicine II, Haematology/Oncology, Immunology and Rheumatology, University Hospital, Otfried-Müller-Str 10, 72076 Tübingen, Germany; ina.koetter@med.uni-tuebingen.de

Accepted 10 July 2003

\section{REFERENCES}

1 Tyndall A. Haematological stem cell transplantation in the treatment of severe autoimmune diseases: first experiences from an international project. Rheumatology (Oxford) 1999;38:774-6.

2 Tyndall A, Fassas A, Passweg J, Ruiz de Elvira C, Attal M, Brooks P, et al. Autologous haematopoietic stem cell transplants for autoimmune diseasefeasibility and transplant-related mortality. Bone Marrow Transplant 1999;24:729-34.

3 Burt RK, Georganas C, Schroeder J, Traynor A, Stefka J, Schuening F, et al. Autologous hematopoietic stem cell transplantation in refractory rheumatoid arthritis. Arthritis Rheum 1999;42:2281-5.

4 Burt RK, Fassas A, Snowden JA, van Laar JM, Kozak T, Wulffraat NM, et al. Collection of hematopoietic stem cells from patients with autoimmune diseases. Bone Marrow Transplant $2001 ; 28: 1-12$.

5 Snowden JA, Biggs JC, Milliken ST, Fuller A, Brooks PM. A phase I/II dose escalation study of intensified cyclophosphamide and autologous blood stem cell rescue in severe, active rheumatoid arthritis. Arthritis Rheum 1999:42:2286-92.

6 Verburg RJ, Kruize AA, van den Hoogen F, Fibbe WE, Petersen EJ, Preijers F, et al. High dose chemotherapy and autologous hematopoietic stem cell transplantation in patients with rheumatoid arthritis. Arthritis Rheum 2001;44:754-60.

7 Breban M, Dougados M, Picard F, Zompi S, Marolleau JP, Bocaccio C, et al Intensified-dose $\left(4 \mathrm{~g} / \mathrm{m}^{2}\right)$ cyclophosphamide and granulocyte colonystimulating factor administration for hematopoietic stem cell mobilization in refractory rheumatoid arthritis. Arthritis Rheum 1999;42:2275-80.

8 Cooley H, Snowden J, Grigg A, Wicks I. Outcome of rheumatoid arthritis and psoriasis following autologous stem cell transplantation for hematologic malignancy. Arthritis Rheum 1997;40:1712-15.

\title{
Peripheral blood lymphocyte phenotypes in patients with spondyloarthropathy
}

\author{
A Plonquet, A Gleizes, K Briot, P Maison, X Chevalier, J-P Farcet, P Claudepierre
}

A prevalent hypothesis in the pathogenesis of the spondyloarthropathies ( $\mathrm{SpA})$ is that gut lymphocytes primed by antigens in the gut lumen may enter the bloodstream and home in on target tissues-for example, the entheses and synovial membranes, where they may initiate a local immune process responsible for further local inflammation. ${ }^{1}$ Selective homing of lymphocytes is a well known process that is made possible, in part, by the lymphocyte phenotype acquired as a response to antigenic stimulation and characterised by a subset of receptors (such as integrins) associated with targeted trafficking. ${ }^{2}$ Among integrins, $\alpha_{\mathrm{E}} \beta_{7}$. is expressed by $\mathrm{T}$ lymphocytes in or adjacent to mucosal epithelia, and exhibits features that indicate a possible role in this pathogenic process. ${ }^{3}{ }^{4}$ To our knowledge, there are no data on the markers for activation and adhesion of circulating lymphocytes in the SpA. The main objective of this study was to look for differences in $\alpha_{E} \beta_{7}$ (CD103) blood lymphocyte counts between patients with active and those with inactive SpA, using flow cytometry. We also studied markers for other adhesion molecules, lymphocyte subsets, and lymphocyte activation.

\section{PATIENTS, METHODS, AND RESULTS}

Twenty patients meeting European Spondylarthropathy Study Group criteria ${ }^{5}$ or Amor's criteria ${ }^{6}$ for SpA were enrolled in the study, together with control patients followed up for chronic degenerative low back pain. They did not have any other underlying disease and only had a non-steroidal anti-inflammatory drug (NSAID) or acetaminophen as current treatment. All patients and controls gave their written informed consent to participation in the study, which was approved by the local ethics committee. Table 1 shows the main characteristics of the patients. The 20 control patients had a mean (SD) age of 39.8 (9.6) years ( $p>0.05 v$ the SpA group) and six of them were men. Flow cytometry was performed using a Coulter EPICS(r) XL within 24 hours after staining. List mode parameters were analysed and stored on System II software (Beckman-Coulter).

The studied markers (absolute count and/or percentage of positive cells) were compared between the patients with SpA and the controls, and between the patients with SpA with active disease and those with quiescent or controlled disease. Active disease was defined a priori as a Bath Ankylosing Spondylitis Disease Activity Index (BASDAI) score $>30^{7}$ with a C reactive protein (CRP) level $>15 \mathrm{mg} / \mathrm{l}$ (Mann-Whitney test).

The mean (SD) percentage of CD103 lymphocytes did not differ between the patients with SpA $(0.9(0.4) \%)$ and controls ( $1(0.6 \%))$, but was significantly lower in the patients with active SpA $(0.66(0.26 \%))$ than in those with inactive SpA $(1.2(0.7) \%, p<0.05)$. Except for a small but significant decrease in the percentage of CD49d positive cells in the patients with SpA as compared with the controls, no significant differences between the groups with active and inactive SpA were seen for any of the three other integrin markers (CD11a, CD29, and CD49d). The frequencies of the main CD4 and CD8 T cell subsets and NK cells were not significantly different between the patients with SpA and controls or between the groups with active and inactive SpA. However, there was a trend toward an increase in the CD3+ lymphocyte count in the group with active SpA, which was 
Table 1 Demographic data and main disease characteristics in the 20 patients with spondyloarthropathy $(\mathrm{SpA})$

\begin{tabular}{lllll}
\hline Characteristics & $\begin{array}{l}\text { All patients with SpA } \\
(\mathbf{n = 2 0 )}\end{array}$ & $\begin{array}{l}\text { Active disease } \\
(\mathbf{n}=\mathbf{7})\end{array}$ & $\begin{array}{l}\text { Inactive disease } \\
(\mathbf{n}=13)\end{array}$ & $\begin{array}{l}\mathbf{p}^{*} \text { (active } \boldsymbol{v} \\
\text { inactive) }\end{array}$ \\
\hline Age (years) & $35.4(9.1)$ & $36.4(7.5)$ & $34.8(10.1)$ & $>0.05$ \\
Sex ratio, M/F & $13 / 7$ & $6 / 1$ & $7 / 6$ & $>0.05$ \\
Disease duration (years) & $8.2(5.6)$ & $10.1(3.1)$ & $7.1(6.5)$ & $>0.05$ \\
Sacroiliitis & 14 & 6 & 8 & $>0.05$ \\
Psoriasis & 4 & 2 & 2 & $>0.05$ \\
Presence of B27 & $16 \dagger$ & 5 & 11 & $>0.05$ \\
BASDAl score & $50.7(22.7)$ & $59.4(13.5)$ & $45.7(25.9)$ & $>0.05$ \\
BASFI score & $40(26.6)$ & $64.2(13)$ & $23.9(20)$ & 0.02 \\
ESR (mm/1 st h) & $22.4(20)$ & $39.5(26.4)$ & $14.5(10.3)$ & 0.05 \\
CRP (mg/l) & $18.2(22)$ & $44.8(17.8)$ & $5.8(8.6)$ & 0.002 \\
\hline
\end{tabular}

Results for quantitative parameters are given as means (SD).

*Comparisons were performed using the $\chi^{2}$ test or Fisher's exact test for qualitative parameters and the MannWhitney test for quantitative parameters; ttwo not done.

BASDAI, Bath Ankylosing Spondylitis Disease Activity Index; BASFI, Bath Ankylosing Spondylitis Functional Index; $E S R$, erythrocyte sedimentation rate; CRP, $C$ reactive protein.

ascribable primarily to a trend towards higher CD8+ T cell counts. The absolute count of CD8+ cells positive for CD62L was significantly greater in the group with active SpA (140 (28)) than in the group with inactive SpA $(77(82), \mathrm{p}<0.05)$, whereas no difference was noted between the overall SpA patient group and the control group. A trend in the same direction was seen for CD4+ lymphocytes, although the difference was not statistically significant. None of the between-group differences for these molecules (CD25, CD38, DR, CD45RA-RO), which can be considered markers of lymphocyte activation, were statistically significant.

\section{DISCUSSION}

This study provides the first data on blood lymphocyte phenotypes according to disease activity in patients with SpA. It found no differences in peripheral blood lymphocyte phenotypes between patients with $\mathrm{SpA}$ and controls. However, a decrease of lymphocytes expressing $\alpha_{\mathrm{E}} \beta_{7}$ integrin was seen in patients with active SpA, which may suggest an accumulation of these cells in tissue and add to earlier evidence $^{8}$ that $\mathrm{T}$ cells expressing $\alpha_{\mathrm{E}} \beta_{7}$ may be involved in the pathogenesis of SpA. The increase in absolute counts of CD8+ T cells expressing L-selectin observed in the same subgroup of patients with active SpA may reflect different immunological processes and also deserves further study.

\section{Authors' affiliations}

K Briot, X Chevalier, P Claudepierre, Department of Rheumatology, Henri Mondor Hospital, France
A Plonquet, A Gleizes, J-P Farcet, Department of Immunology, Henri Mondor Hospital, France

P Maison, Clinical Research Unit, Henri Mondor Hospital, France

Correspondence to: Dr P Claudepierre, Service de Rhumatologie, Hôpital Henri Mondor, 94010 Créteil, cedex Créteil, France; pascal.claudepierre@hmn.ap-hop-paris.fr

Accepted 27 May 2003

\section{REFERENCES}

1 Wolheim FA. Enteropathic arthritis: how do the joints talk with the gut? Curr Opin Rheumatol 2001;13:305-9.

2 Butcher EC, Picker L. Lymphocyte homing and homeostasis. Science 1996;272:60-6.

3 Cerf-Bensussan N, Jarry A, Brousse N, Lisowska-Grospierre B, Guy-Grand D Griscelli C. A monoclonal antibody (HML-1) defining a novel membrane molecule present on human intestinal lymphocytes. Eur J Immunol 1987; 17:1279-85.

4 Elewaut D, De Keyser F, Van den Bosch F, Lazarovits Al, De Vos M, Cuvelier C, et al. Enrichment of $T$ cells carrying $\beta 7$ integrins in inflamed synovial tissue from patients with early spondyloarthropathy, compared to rheumatoid arthritis. J Rheumatol 1998;25:1932-7.

5 Dougados M, van der Linden S, Juhlin R, Huiffeldt B, Amor B, Calin A, et al. The European Spondylarthropathy Study Group preliminary criteria for the classification of spondyloarthropathy. Arthritis Rheum 1991;34:1218-27.

6 Amor B, Dougados M, Mijiyawa M. Critères diagnostiques des spondylarthropathies. Rev Rhum Mal Osteoartic 1990:57:85-9.

7 Garrett S, Jenkinson T, Whitelock H, Kennedy G, Gaisford P, Calin A. A new approach to defining disease status in AS: the Bath Ankylosing Spondylitis Disease Activity Index (BASDAl). J Rheumatol 1994;21:2286-91.

8 Elewaut D, De Keyser F, Van den Bosch F, Lazarovits Al, De Vos M, Cuvelier C, et al. Enrichment of $T$ cells carrying $\beta 7$ integrins in inflamed synovial tissue from patients with early spondyloarthropathy, compared to rheumatoid arthritis. J Rheumatol 1998;25:1932-7.

\section{EULAR Teach the Teachers Workshop}

5-9 May 2004; Vidago Palace Hotel, Vidago, Portugal

EULAR is proud to announce the organisation of this workshop devoted to the discussion and exchange of best practice in curriculum design, teaching, and assessment methods for musculoskeletal diseases in undergraduate medical courses.

This meeting is designed to guarantee an intensive interactive format in a charming venue.

For more information on the programme, venue, registration fees, and transportation visit the EULAR website at:

hHtp://www.eular.org

under "courses" or see:

http://www.aims-international.com/teachersworkshop

for registration and programme information. 